Short Communication

\title{
Absence of TERT promoter mutations in colorectal precursor lesions and cancer
}

\author{
${\text { Adriana Cruvinel-Carloni }{ }^{1 *} \text {, Letícia Yamane }}^{1^{*}}$, Cristovam Scapulatempo-Neto ${ }^{1,2}$, Denise Guimarães ${ }^{1,3}$ and \\ Rui Manuel Reis ${ }^{1,4,5}$ \\ ${ }^{1}$ Molecular Oncology Research Center, Hospital de Câncer de Barretos, Barretos, SP, Brazil. \\ ${ }^{2}$ Department of Pathology, Hospital de Câncer de Barretos, Barretos, São Paulo, Brazil. \\ ${ }^{3}$ Department of Endoscopy, Hospital de Câncer de Barretos, Barretos, São Paulo, Brazil. \\ ${ }^{4}$ Life and Health Sciences Research Institute (ICVS), School of Health Sciences, University of Minho, Braga, \\ Portugal. \\ ${ }^{5}$ ICVS/3B's - PT Government Associate Laboratory, Braga/Guimarães, Portugal.
}

\begin{abstract}
Hotspot mutations (c.-124bp G > A and c.-146bp G > A) in the promoter region of the TERT gene have been recently described in several types of solid tumors, including glioma, bladder, thyroid, liver and skin neoplasms. However, knowledge with respect to colorectal precursor lesions and cancer is scarce. In the present study we aimed to determine the frequency of hotspot TERT promoter mutations in 145 Brazilian patients, including 103 subjects with precursor lesions and 42 with colorectal carcinomas, and we associated the presence of such mutations with the patients clinical-pathological features. The mutation analysis was conclusive in 123 cases, and none of the precursor and colorectal carcinoma cases showed TERT promoter mutations. We conclude that TERT mutations are not a driving factor in colorectal carcinogenesis.
\end{abstract}

Keywords: colorectal carcinoma; TERT promoter mutations, precursor lesions.

Received: May 17, 2017; Accepted: Octuber 13, 2017.

Colorectal cancer (CRC) is the third most frequent type of cancer worldwide (Ferlay et al., 2015). This scenario shows the importance to improve strategies for CRC prevention and early detection to decrease its incidence and mortality (Goss et al., 2013). CRC arises from a stepwise evolution of normal mucosa to precursor lesions and ultimately to a malignant tumor. The adenoma is the most commonly reported precursor lesion of CRC (Fearon and Vogelstein, 1990; Lieberman et al., 2000). However, alternative precursor lesions include the serrated polyp, which was recently described as a precursor lesion of CRC. Serrated polyps are known to be a heterogeneous group of colorectal lesions that include hyperplasic polyps (HPs), sessile serrated adenoma (SSA), traditional serrated adenoma (TSA) and mixed polyps. Clinically, HPs are the most common precursor serrated lesions of CRC (Yamane et al., 2014). Serrated adenocarcinomas accounts for about $10 \%$ of all CRCs (Makinen, 2007).

Send correspondence to Rui Manuel Reis. Molecular Oncology Research Center, Barretos Cancer Hospital, Rua Antenor Duarte Villela 1331. 14784-400 Barretos, SP, Brazil. E-mail: ruireis.hcb@gmail.com

* These authors contributed equally to this study
The classic genetic model for colorectal tumorigenesis is driven by the progressive accumulation of a series of critical mutations in cancer-related genes, such as APC and KRAS (Fearon and Vogelstein, 1990). Since the molecular alterations among serrated pathways are less understood, the BRAF gene has now emerged as a prevalent marker in this pathway (Yamane et al., 2014). With the presence of these genetic alterations, molecular biomarkers have been widely proposed as a means of CRC screening and prevention (Imperiale and Ransohoff, 2010).

Recently, hotspot somatic mutations in the TERT promoter region (c.-124bp G > A and c.-146bp G > A) have been described in several tumors, particularly skin, brain, thyroid and bladder cancers (Horn et al., 2013; Huang et al., 2013; Killela et al., 2013; Vinagre et al., 2013; Heidenreich et al., 2014). The TERT gene encodes a telomerase reverse transcriptase, an essential protein for preserving telomere genomic integrity. These mutations result in the creation of new binding motif sites (GGAA) for ETS transcription factors, leading to an increase in TERT activity and subsequent telomere preservation (Horn et al., 2013; Huang et al., 2013). Additionally, these hotspot mutations have been associated with advanced tumor stages and poor prognosis for patients (Killela et al., 2013; Vinagre et al., 
2013; Heidenreich et al., 2014). Currently, only one study evaluated TERT mutation frequency in CRC, and no muta-

Table 1 - Clinicopathological and molecular features of all patients.

\begin{tabular}{|c|c|c|c|}
\hline Variables & & $\mathrm{N}$ & $\%$ \\
\hline Age & $\begin{array}{l}66.0 \text { y mean (range } \\
51-89 \text { ) }\end{array}$ & 145 & - \\
\hline \multirow[t]{2}{*}{ Gender } & Female & 71 & 49.0 \\
\hline & Male & 74 & 51.0 \\
\hline \multirow[t]{4}{*}{ Histology } & Adenocarcinoma & 42 & 29.0 \\
\hline & Adenoma polyps & 50 & 34.5 \\
\hline & Serrated polyps & 15 & 10.3 \\
\hline & Hyperplastic polyps & 38 & 26.2 \\
\hline \multirow[t]{2}{*}{ Precursor Lesion Location } & Right colon & 39 & 37.9 \\
\hline & Left colon & 64 & 62.1 \\
\hline \multirow[t]{2}{*}{ Carcinoma Location } & Right colon & 24 & 57.1 \\
\hline & Left colon & 18 & 42.9 \\
\hline \multirow[t]{2}{*}{ Precursor Lesion Morphology } & Polypoid & 83 & 81.4 \\
\hline & Non polypoid & 19 & 18.6 \\
\hline \multirow[t]{2}{*}{ Precursor Lesion Size (mm) } & $<10$ & 91 & 90.1 \\
\hline & $\geq 10$ & 10 & 9.9 \\
\hline \multirow[t]{3}{*}{ Precursor Lesion MSI Status } & MSS & 96 & 96.0 \\
\hline & MSI-L & 4 & 4.0 \\
\hline & MSI-H & 0 & 0.0 \\
\hline \multirow[t]{3}{*}{ Carcinoma MSI Status } & MSS & 35 & 83.3 \\
\hline & MSI-L & 2 & 4.8 \\
\hline & MSI-H & 5 & 11.9 \\
\hline \multirow[t]{2}{*}{ Precursor Lesion $K R A S$ Status } & MUT & 14 & 13.6 \\
\hline & WT & 89 & 86.4 \\
\hline \multirow[t]{2}{*}{ Precursor Lesion $B R A F$ Status } & MUT & 9 & 8.7 \\
\hline & WT & 94 & 91.3 \\
\hline \multirow[t]{2}{*}{ Carcinoma KRAS Status } & MUT & 20 & 47.6 \\
\hline & WT & 22 & 52.4 \\
\hline \multirow[t]{2}{*}{ Carcinoma $B R A F$ Status } & MUT & 2 & 4.8 \\
\hline & WT & 40 & 95.2 \\
\hline
\end{tabular}

MUT, mutated; WT, wild type; MSI-L, microsatellite instability low; MSI-H, microsatellite instability high; MSS, microsatellite stability. tions were found in colorectal adenocarcinomas (Killela et al., 2013).

Herein, we investigated the frequency of TERT mutations in a series of Brazilian patients with colorectal precursor and cancer lesions. We analyzed 145 Brazilian patients from the Barretos Cancer Hospital. The clinico-pathological and molecular features of the patients were previously reported (Table 1) (Yamane et al., 2014). All included patients were over 50 years old, with a mean age of 66 years (ranging from $51-89$ ), with similar frequency for both genders. Patients with known family history, hereditary $\mathrm{CRC}$, or bowel inflammatory disease were excluded. All cases were reviewed by an expert pathologist and categorized according to the WHO classification. Tumor DNA was isolated from formalin-fixed paraffin-embedded (FFPE) tumor tissue, as previously reported (Yamane et al., 2014). TERT promoter mutations were identified by PCR followed by direct sequencing as described elsewhere (Vinagre et al., 2013; Batista et al., 2016).

Of the 145 samples analyzed, 22 were inconclusive due to poor quality/quantity of DNA. The evaluation of hotspot TERT promoter mutations showed that all precursor and cancer lesions (123 samples), which included 45 adenoma polyps, 15 serrated polyps, 22 hyperplastic polyps and 41 adenocarcinomas, were wild-type (Figure 1). Our results are in agreement with a previous report that showed the absence of TERT promoter mutation in colorectal adenocarcinomas (Killela et al., 2013). We also showed for the first time, that these mutations are absent in precursor lesions as well. Furthermore, it is the first study to analyze the TERT mutation status in Brazilian colorectal disease patients.

Telomere length is a major tumor hallmark (Heidenreich et al., 2014). Besides hotspot TERT promoter mutations, other pathways are involved with an increase in telomere length (Heidenreich et al., 2014). One such mechanism is the alternative lengthening of telomeres (ATL) (Cesare and Reddel, 2010; Killela et al., 2013). However, a previous study reported the absence this pathway in CRC (Heaphy et al., 2011). Therefore, the mechanisms of telomere length variation in colorectal tumors are still unknown.

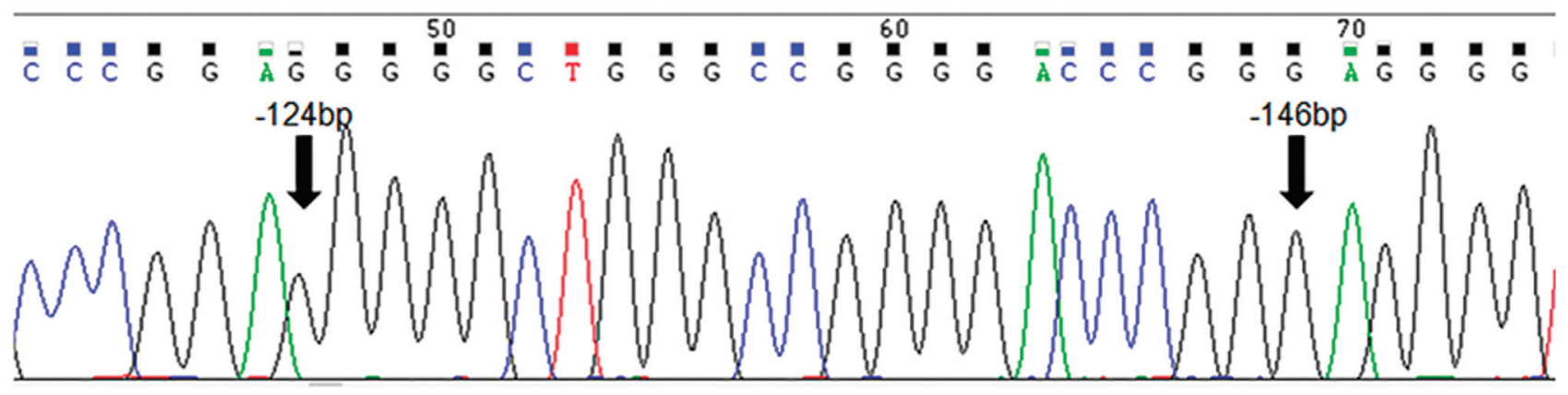

Figure 1 - Electropherogram of TERT showing the wild-type sequence for both hotspot mutation regions. The arrows indicate the hotspot mutation regions (-124bp and -146bp). 
Concluding, we analyzed for the first time the presence of TERT promoter mutations in precursor and carcinoma colorectal lesions in Brazilian patients. The results showed the lack of TERT promoter mutations, suggesting that these alterations are not involved in CRC carcinogenesis.

\section{Acknowledgments}

The authors acknowledge the help of Elliot Goodfellow in English editing. This study was financially partially supported by Barretos Cancer Hospital Internal Research Funds (PAIP) to participating authors. Rui Manuel Reis is recipient of a National Council of Technological and Scientific Development (CNPq) scholarship.

\section{References}

Batista R, Cruvinel-Carloni A, Vinagre J, Peixoto J, Catarino TA, Campanella NC, Menezes W, Becker AP, de Almeida GC, Matsushita MM, et al. (2016) The prognostic impact of TERT promoter mutations in glioblastomas is modified by the rs2853669 single nucleotide polymorphism. Int J Cancer 139:414-423.

Cesare AJ and Reddel RR (2010) Alternative lengthening of telomeres: Models, mechanisms and implications. Nat Rev Genet 11:319-330.

Fearon ER and Vogelstein B (1990) A genetic model for colorectal tumorigenesis. Cell 61:759-767.

Ferlay J, Soerjomataram I, Dikshit R, Eser S, Mathers C, Rebelo M, Parkin DM, Forman D and Bray F (2015) Cancer incidence and mortality worldwide: sources, methods and major patterns in GLOBOCAN 2012. Int J Cancer 136:E359E386.

Goss PE, Lee BL, Badovinac-Crnjevic T, Strasser-Weippl K, Chavarri-Guerra Y, St Louis J, Villarreal-Garza C, UngerSaldana K, Ferreyra M, Debiasi M, et al. (2013) Planning cancer control in Latin America and the Caribbean. Lancet Oncol 14:391-436.

Heaphy CM, Subhawong AP, Hong SM, Goggins MG, Montgomery EA, Gabrielson E, Netto GJ, Epstein JI, Lotan TL, Westra WH, et al. (2011) Prevalence of the alternative lengthening of telomeres telomere maintenance mechanism in human cancer subtypes. Am J Pathol 179:1608-1615.

Heidenreich B, Rachakonda PS, Hemminki K and Kumar R (2014) TERT promoter mutations in cancer development. Curr Opin Genet Dev 24:30-37.

Horn S, Figl A, Rachakonda PS, Fischer C, Sucker A, Gast A, Kadel S, Moll I, Nagore E, Hemminki K, et al. (2013) TERT promoter mutations in familial and sporadic melanoma. Science 339:959-961.

Huang FW, Hodis E, Xu MJ, Kryukov GV, Chin L and Garraway LA (2013) Highly recurrent TERT promoter mutations in human melanoma. Science 339:957-959.

Imperiale TF and Ransohoff DF (2010) Understanding differences in the guidelines for colorectal cancer screening. Gastroenterology 138:1642-1647.

Killela PJ, Reitman ZJ, Jiao Y, Bettegowda C, Agrawal N, Diaz Jr LA, Friedman AH, Friedman H, Gallia GL, Giovanella BC, et al. (2013) TERT promoter mutations occur frequently in gliomas and a subset of tumors derived from cells with low rates of self-renewal. Proc Natl Acad Sci U S A 110:60216026.

Lieberman DA, Weiss DG, Bond JH, Ahnen DJ, Garewal H and Chejfec G (2000) Use of colonoscopy to screen asymptomatic adults for colorectal cancer. Veterans Affairs Cooperative Study Group 380. N Engl J Med 343:162-168.

Makinen MJ (2007) Colorectal serrated adenocarcinoma. Histopathology 50:131-150.

Vinagre J, Almeida A, Populo H, Batista R, Lyra J, Pinto V, Coelho R, Celestino R, Prazeres H, Lima L, et al. (2013) Frequency of TERT promoter mutations in human cancers. Nat Commun 4:2185.

Yamane L, Scapulatempo-Neto C, Reis RM and Guimaraes DP (2014) Serrated pathway in colorectal carcinogenesis. World J Gastroenterol 20:2634-2640.

Yamane LS, Scapulatempo-Neto C, Alvarenga L, Oliveira CZ, Berardinelli GN, Almodova E, Cunha TR, Fava G, Colaiacovo W, Melani A, et al. (2014) KRAS and BRAF mutations and MSI status in precursor lesions of colorectal cancer detected by colonoscopy. Oncol Rep 32:1419-1426.

Associate Editor: Jeremy A. Squire

License information: This is an open-access article distributed under the terms of the Creative Commons Attribution License (type CC-BY), which permits unrestricted use, distribution and reproduction in any medium, provided the original article is properly cited. 